\title{
Desain U-slot Ganda untuk Meningkatkan Bandwidth Antena MIMO 5 G Millimeter-wave
}

\author{
EFRI SANDI, WISNU DJATMIKO, RIZKITA KURNIA PUTRI \\ KBI Elektronika Komunikasi Universitas Negeri Jakarta, Indonesia \\ Email: efri.sandi@unj.ac.id
}

Received 20 April 2019 | Revised 19 Juli 2019 | Accepted 8 November 2019

\begin{abstract}
ABSTRAK
Pada penelitian ini dikembangkan rekayasa antena mikrostrip (MSA) dengan penambahan U-slot ganda untuk meningkatkan performansi bandwidth antena mikrostrip. Penelitian sebelumnya berfokus pada penambahan U-slot tunggal dan didesain untuk frekuensi di bawah $15 \mathrm{GHz}$. Kebutuhan utama antena $5 \mathrm{G}$ adalah memiliki bandwidth yang lebar dan kemampuan Multiple Input Multiple Output (MIMO). Untuk itu perlu dikembangkan desain antena MIMO $5 \mathrm{G}$ dengan bandwidth yang lebih lebar pada frekuensi millimeter-wave $28 \mathrm{GHz}$ sebagai kandidat utama alokasi frekuensi untuk komunikasi seluler 5G. Pada penelitian ini diajukan teknik desain antena MIMO dengan penambahan rekayasa U-slot ganda untuk meningkatkan performansi bandwidth. Hasil kalkulasi dan simulasi menunjukkan bahwa dengan penambahan U-slot ganda, dihasilkan peningkatan performansi bandwith sebesar $68 \%$ dibandingkan desain antena tanpa U-slot. Jika dibandingkan dengan hasil penelitian U-slot sebelumnya, penambahan U-slot ganda menghasilkan peningkatan bandwidth sebesar $76 \%$.
\end{abstract}

Kata kunci: U-Slot ganda, antena 5 G millimeter-wave, MIMO, bandwidth

\begin{abstract}
In this study, a microstrip antenna (MSA) was developed with the addition of a double U-slot to improve bandwidth performance. Previous studies have focused on adding single U-slots and designed for frequencies below $15 \mathrm{GHz}$. The main requirement for $5 \mathrm{G}$ antennas is high bandwidth performance and multiple inputmultiple output capabilities (MIMO). Therefore, it is necessary to develop a $5 G$ MIMO antenna with broader bandwidth at the millimeter-wave frequency $28 \mathrm{GHz}$ as the primary candidate for frequency allocation for $5 \mathrm{G}$ cellular communication. In this study, MIMO antenna design techniques were proposed with the addition of a double U-slot method to improve bandwidth performance. The calculation and simulation results show that with the addition of a double U-slot, an increase in bandwidth performance of $68 \%$ compared to antenna designs without U-slots and $76 \%$ when compared to using a single U-slot in previous studies.
\end{abstract}

Keywords: Double U-Slot, millimeter-wave $5 G$ antenna, MIMO, bandwidth 


\section{PENDAHULUAN}

Perkembangan teknologi komunikasi seluler saat ini dalam tahap memasuki generasi ke-5 (5G) yang mempunyai tantangan untuk mencapai kecepatan tinggi, efisiensi daya dan keandalan sistem (Warren \& Dewar, 2014). Menurut (Ericsson Ab, 2016), parameter teknologi $5 G$ akan mengembangkan kecepatan data yang sangat tinggi, reabilitas tinggi, latensi yang sangat rendah dan konsumsi energi yang efisien. International Telecommunication Union (ITU) dalam (ITU-R.2083-0), merekomendasikan parameter kunci yang harus dipenuhi dalam pengembangan teknologi $5 \mathrm{G}$ adalah kecepatan data 10-20 Gbit/s, kecepatan penerimaan (user experiences) $100 \mathrm{Mbit} / \mathrm{s}$, latency $1 \mathrm{~ms}$, kemampuan mobility $500 \mathrm{~km} / \mathrm{h}$, connection density 106 perangkat $/ \mathrm{km}^{2}$, efisiensi energi 100 kali IMT-Advanced, efisiensi spektrum 3 kali IMT-Advanced serta kapasitas area trafik $10 \mathrm{Mbit} / \mathrm{s} / \mathrm{m}^{2}$.

Salah satu perangkat penting dalam teknologi $5 \mathrm{G}$ adalah perangkat antena yang mendukung kinerja jaringan teknologi $5 \mathrm{G}$. Teknologi seluler $5 \mathrm{G}$ membutuhkan antena yang mempunyai performansi tinggi, sistem transmisi Multiple Input-Multiple Output (MIMO) dan beamforming (Swindlehurst, dkk, 2014). Menurut (Ancans, dkk, 2017) terdapat beberapa kandidat alokasi frekuensi pada daerah millimeter-wave yang dapat digunakan untuk mendukung kebutuhan spektrum lebar sistem komunikasi 5G. (Kim, dkk, 2016) merekomendasikan teknologi $5 \mathrm{G}$ bekerja pada frekuensi millimeter-wave (24-28 GHz). Khusus untuk Indonesia, penelitian (Hikmaturokhman, dkk, 2018) merekomendasikan teknologi $5 G$ bekerja pada daerah C-Band dan millimeter-wave $28 \mathrm{GHz}$. Dengan demikian, dibutuhkan desain dan pengembangan antena $5 \mathrm{G}$ yang bekerja pada frekuensi millimeter-wave untuk mengantisipasi kebutuhan teknologi $5 \mathrm{G}$ yang akan segera diluncurkan.

Salah satu jenis antena yang banyak digunakan dalam aplikasi sistem komunikasi saat ini adalah antena mikrostrip. Antena mikrostrip dipilih karena memiliki kelebihan dari ukuran fisik antena, profil yang sederhana dan mudah difabrikasi. Namun, antena mikrostrip mempunyai kelemahan dari sisi bandwidth yang sempit, keterbatasan gain dan efisiensi yang rendah (Garg, 2000). Dalam berbagai penelitian dan rekayasa antena mikrostrip, para perancang antena telah berusaha mencari solusi untuk meningkatkan performansi bandwidth dan gain antena mikrostrip. Salah satu teknik yang dikembangkan adalah menggunakan patch slot berbentuk $U$ untuk memberikan pelebaran bandwidth dengan meningkatkan kopling induktif dan mengurangi faktor Q antena (V.P Patil, 2012).

Beberapa penelitian lainnya menunjukkan pengaruh penambahan U-S/ot terhadap peningkatan performansi bandwidth antena mikrostrip. Penelitian (Kevin, dkk, 2017) mengusulkan perancangan antena rectangular patch dengan U-slot pada frekuensi $15 \mathrm{GHz}$. Hasil penelitian ini dapat meningkatkan bandwidth sebesar $400 \mathrm{MHz}$ dibandingkan dengan antena tanpa U-slot. Penelitian (Darimireddy, dkk, 2015) mengusulkan perancangan antena triple layer dengan double U-slot pada frekuensi $3.8 \mathrm{GHz}$ menghasilkan performansi bandwidth sebesar $600 \mathrm{MHz}$. Selanjutnya penelitian (Suaibur, dkk, 2013) mengusulkan perancangan double U-slot patch antena untuk aplikasi WiMAX menghasilkan peningkatan bandwidth sebesar $4.22 \%, 1.87 \%$, dan $3.51 \%$ pada setiap band WiMAX dan terakhir pada penelitian (Ardianto, dkk, 2019) penggunaan U-s/ot mampu menghasilkan bandwidth sebesar 1,62 GHz dan gain sebesar 7,52 dB pada frekuensi $28 \mathrm{GHz}$. Hasil-hasil penelitian ini menunjukkan bahwa penambahan $U$-slot pada elemen peradiasi (patch) antena mikrostrip telah terbukti mampu meningkatkan performansi bandwidth antena.

Sehingga dalam penelitian ini dikembangkan rekayasa $U$-slot dengan pengembangan desain $U$-slot ganda pada frekuensi millimeter-wave teknologi seluler 5G. Diharapkan hasil rekayasa 
dan pengembangan desain U-slot ganda ini mampu memperlebar bandwidth dan meningkatkan gain antenna MIMO $5 \mathrm{G}$ dibandingkan dengan hasil-hasil penelitian sebelumnya sehingga mampu memenuhi spesifikasi teknologi $5 \mathrm{G}$ pita lebar dan high gain.

\section{DESAIN DAN PERANCANGAN ANTENA}

\subsection{Antena Mikrostrip}

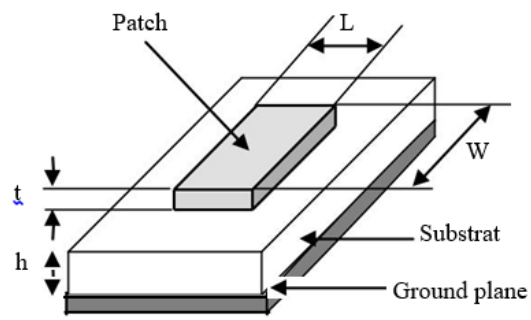

Gambar 1. Struktur Antena Mikrostrip (Balanis, 2005)

Antena mikrostrip didefenisikan sebagai salah satu jenis antena yang mempunyai bentuk seperti potongan yang mempunyai ukuran sangat tipis/kecil. Antena mikrostrip terdiri dari tiga lapisan. Lapisan tersebut adalah conducting patch, substrate dielektrik, dan ground plane seperti yang terdapat pada Gambar 1.

\subsection{Spesifikasi Antena}

Penentuan spesifikasi antena berdasarkan tujuan perancangan, yaitu membuat antena mikrostrip yang sesuai dengan kriteria pada aplikasi teknologi seluler $5 \mathrm{G}$ pada daerah frekuensi millimeter-wave. Adapun spesifikasi yang diharapkan dapat dicapai oleh antena yang akan dirancang ditampilkan pada Tabel 1.

Tabel 1. Spesifikasi Rancangan Antena

\begin{tabular}{|c|c|}
\hline Parameter & Keterangan \\
\hline Frekuensi Kerja & $27-29 \mathrm{GHz}$ \\
\hline Frekuensi Tengah & $28 \mathrm{GHz}$ \\
\hline Bandwidth & $\geq 2 \mathrm{GHz}$ \\
\hline Impedansi & $50 \Omega$ \\
\hline Gain & $\geq 9 \mathrm{~dB}$ \\
\hline VSWR & $\leq 1,5$ \\
\hline Return Loss & $\leq-20 \mathrm{~dB}$ \\
\hline Side Lobe Level & $\leq-13 \mathrm{~dB}$ \\
\hline
\end{tabular}

\subsection{Perancangan Desain Antena}

Metode dan proses perancangan antena $5 \mathrm{G}$ ini dimulai dari tahap kalkulasi untuk menentukan beberapa parameter dimensi patch dan substrate antena, yang dibutuhkan untuk frekuensi millimeter-wave $28 \mathrm{GHz}$. Perancangan dimensi antena ditentukan berdasarkan persamaan 
yang umum digunakan dalam mengihitung dimensi mikrostrip (Balanis, 2005). Untuk menghitung lebar patch (W) menggunakan Persamaan (1) :

$$
W=\frac{C}{2 \mathrm{f}_{\mathrm{r}} \sqrt{\frac{\varepsilon_{\mathrm{r}}+1}{2}}}
$$

$\mathrm{c}=$ Kecepatan cahaya pada ruang bebas $\left(3 \times 10^{8} \mathrm{~m} / \mathrm{s}\right)$

$\mathrm{f}_{\mathrm{r}}=$ Frekuensi kerja antena yang diingin kan $(\mathrm{Hz})$

$\varepsilon_{\mathrm{r}}=$ Permitivitas substrat

untuk menghitung panjang patch (Lp) dirumuskan sebagai berikut,

menghitung $\varepsilon_{e f f}$,

$$
\varepsilon_{e f f}=\frac{\varepsilon_{r}+1}{2}+\frac{\varepsilon_{r-1}}{1}\left[\frac{1}{\sqrt{1+12 \frac{h}{W_{F}}}}+0.04\left(1-\frac{W_{F}}{h}\right)^{2}\right]
$$

menghitung $\Delta \mathrm{L}$,

$$
\Delta \mathrm{L}=0.42 \times h \frac{\left(\varepsilon_{e f f}+0.3\right)\left(\frac{w}{h}+0.264\right)}{\left(\varepsilon_{e f f}-0.258\right)\left(\frac{w}{h}+0.8\right)}
$$

menghitung $\mathrm{L}$ (patch),

$$
\mathrm{L}=\frac{1}{2 x f x \sqrt{\varepsilon_{e f f}} \times \sqrt{\mu_{0} \varepsilon_{r}}}-2 x \Delta L
$$

untuk menentukan lebar ground plane dan substrate,

$$
\mathrm{W}_{g}=6 \mathrm{~h}+\mathrm{W}
$$

untuk menentukan panjang ground plane dan substrate.

$$
\mathrm{L}_{\boldsymbol{g}}=6 h+\mathrm{L}
$$

Untuk menentukan dimensi U-slot dirumuskan melalui pendekatan berikut, (Kevin, dkk, 2017).

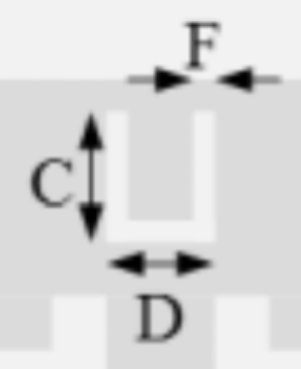

Gambar 2. Struktur U-slot (Kevin, 2017) 
Penambahan struktur $U$-slotpada patch harus menggunakan perhitungan parameter $\mathrm{C}, \mathrm{D}$, dan F sesuai dengan persamaan berikut (Kevin, dkk, 2017):

$$
\begin{gathered}
\frac{C}{W} \geq 0.3 \\
D=\frac{C}{f_{\text {low } \sqrt{\varepsilon_{e f f}}}}-2(L+\Delta L-F) \\
F=\frac{\lambda}{60}
\end{gathered}
$$

Bahan yang digunakan dalam perancangan antena mikrostrip ini adalah tembaga pada patch dan groundplane setebal 0,035 mm. Bahan substrate digunakan Duroid RT5880 dengan permitivitas $\left(\varepsilon_{\mathrm{r}}\right)$ sebesar 2,2 dan tebal yang digunakan adalah 1,575 $\mathrm{mm}$. Hasil rancangan antena U-slot ganda untuk antena MIMO 5G millimeter-wave disimulasikan menggunakan software CST Microwave Studio 2016 seperti ditunjukkan pada Gambar 3 dan Gambar 4.

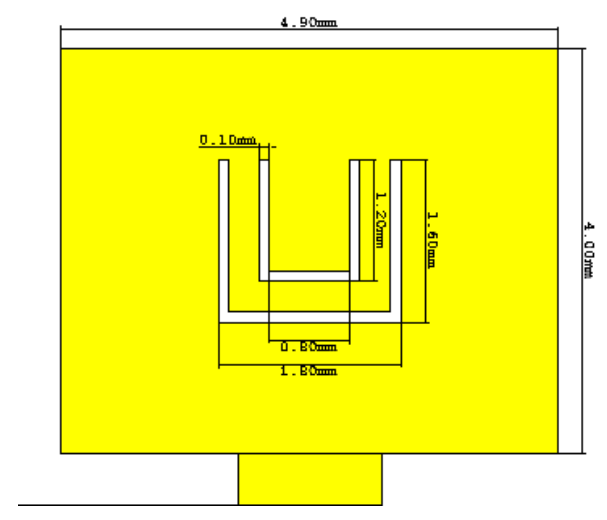

Gambar 3. Dimensi U-Slot

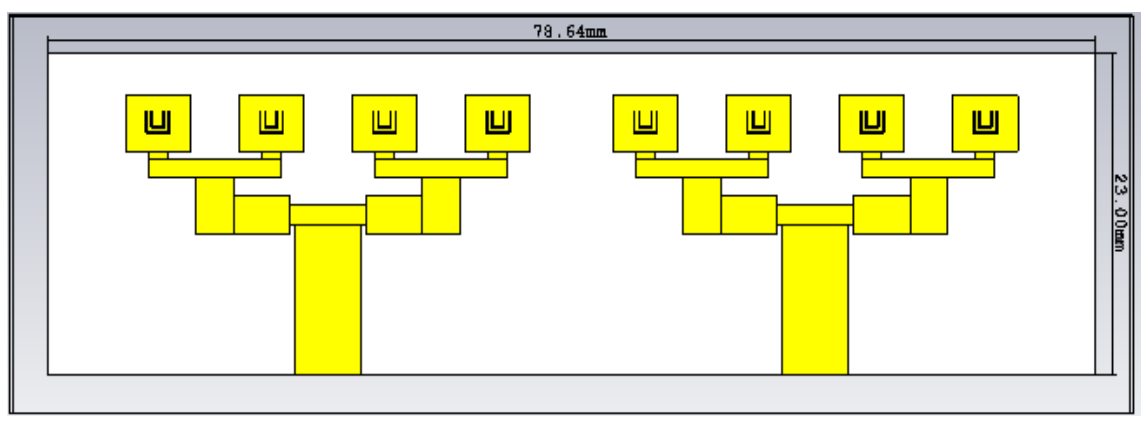

Gambar 4. Antena MIMO 2T2R (2 Transmit 2 Receive)

\section{HASIL SIMULASI DAN ANALISIS}

\subsection{Hasil Simulasi Antena menggunakan $U$-slot Ganda}

Proses simulasi akan menghasilkan nilai-nilai parameter performansi antena yang dirancang sehingga pada saat proses fabrikasi performa antena sudah dapat diketahui kemampuannya. Untuk mendapatkan frekuensi kerja sesuai spesifikasi yang diinginkan, maka return loss pada 
rentang frekuensi $27 \mathrm{GHz}-29 \mathrm{GHz}$ bernilai $\leq-20 \mathrm{~dB}$. Pada Gambar 5 didapatkan nilai return Ioss di ANTENA 1 pada frekuensi tengah $28,023 \mathrm{GHz}$ sebesar $-20,35 \mathrm{~dB}$ dengan bandwidth sebesar 2,845 GHz. Pada Gambar 6 diperoleh nilai return loss ANTENA 2 pada frekuensi tengah 28,023 GHz sebesar -20.34 dB dengan bandwidth sebesar 2,823 GHz.

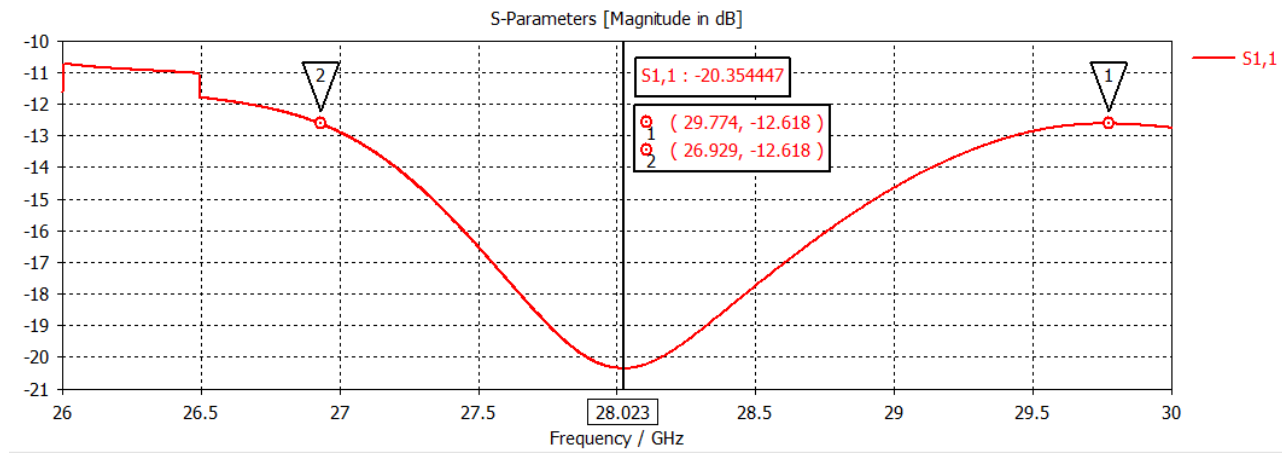

Gambar 5. Return Loss dan Bandwidth Antena 1

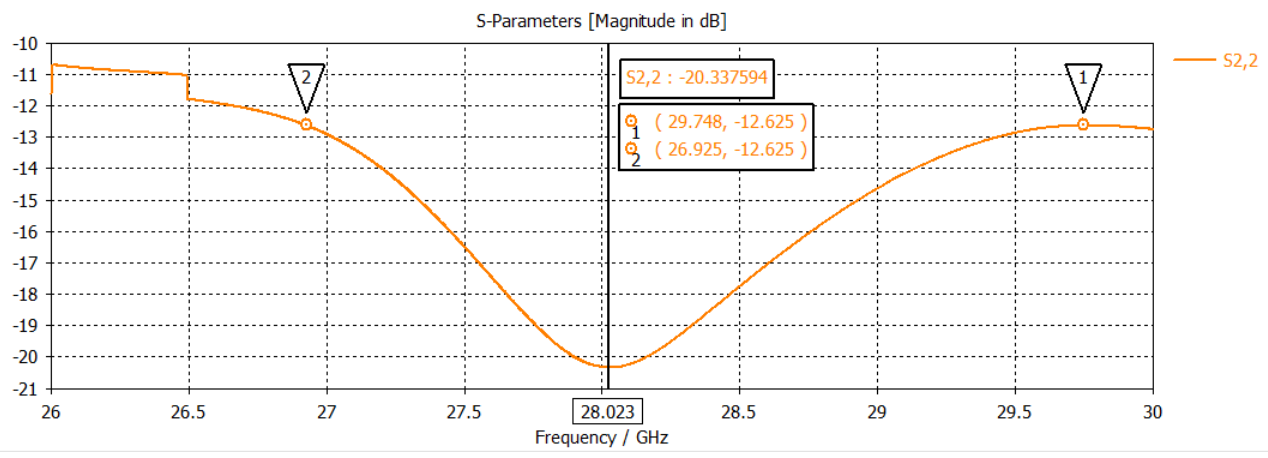

Gambar 6. Return Loss dan Bandwidth Antena 2

Besarnya gain yang diinginkan berdasarkan Tabel 1 adalah $\geq 9 \mathrm{~dB}$. Pada Gambar 7 didapatkan nilai gain maksimum di ANTENA 1 pada frekuensi $28 \mathrm{GHz}$ sebesar 11,16 dB dan pada Gambar 8 didapatkan nilai gain maksimum di ANTENA 2 pada frekuensi $28 \mathrm{GHz}$ sebesar 11,15 dB.

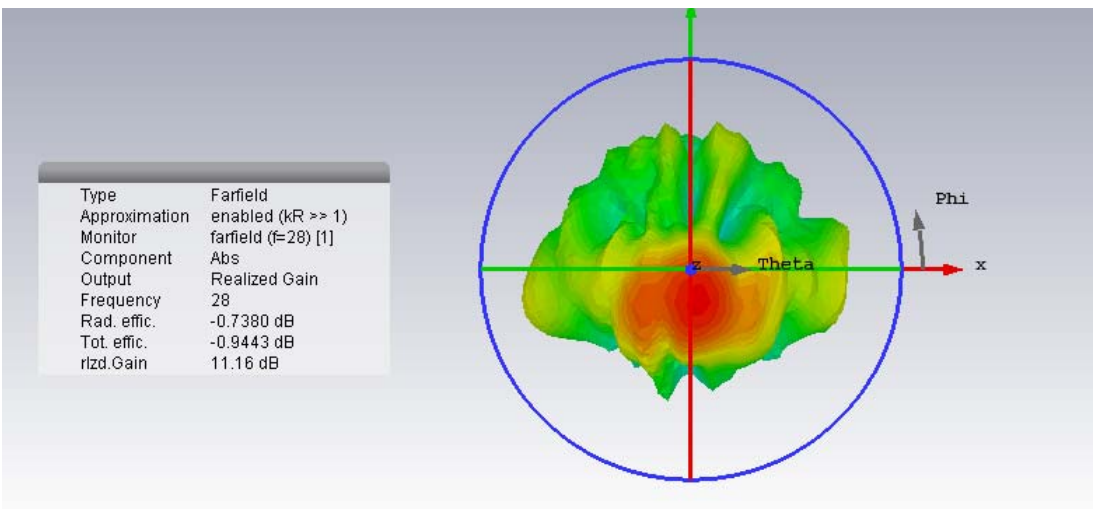

Gambar 7. Gain Antena 1 


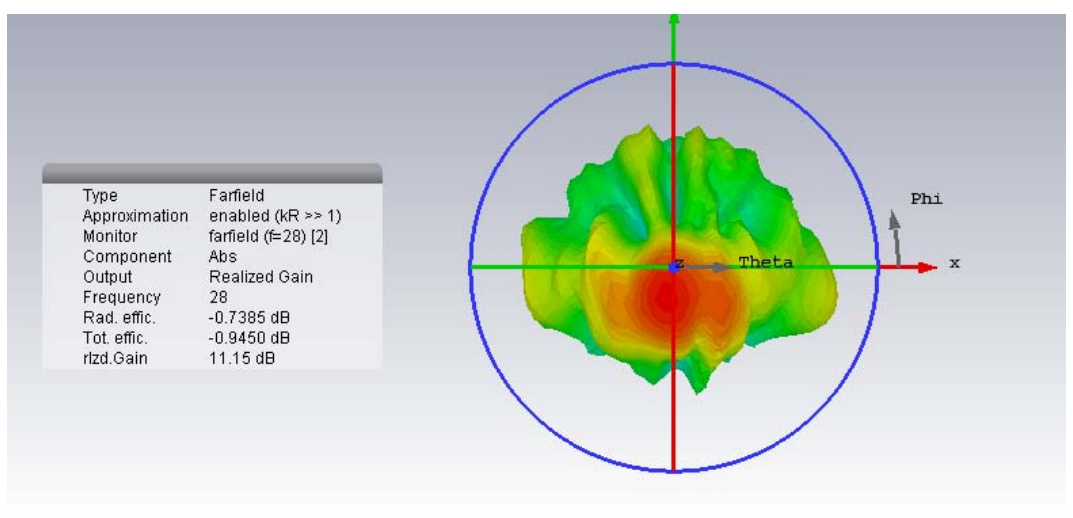

Gambar 8. Gain Antena 2

Besarnya VSWR yang diinginkan berdasarkan Tabel 1 adalah $\leq 1,5$. Pada Gambar 9 didapatkan nilai VSWR minimum di ANTENA 1 berada pada frekuensi tengah 28,028 GHz dengan nilai sebesar 1,212 dan pada Gambar 10 didapatkan nilai VSWR minimum di ANTENA 2 pada frekuensi tengah 28,023 GHz dengan nilai sebesar 1,213.

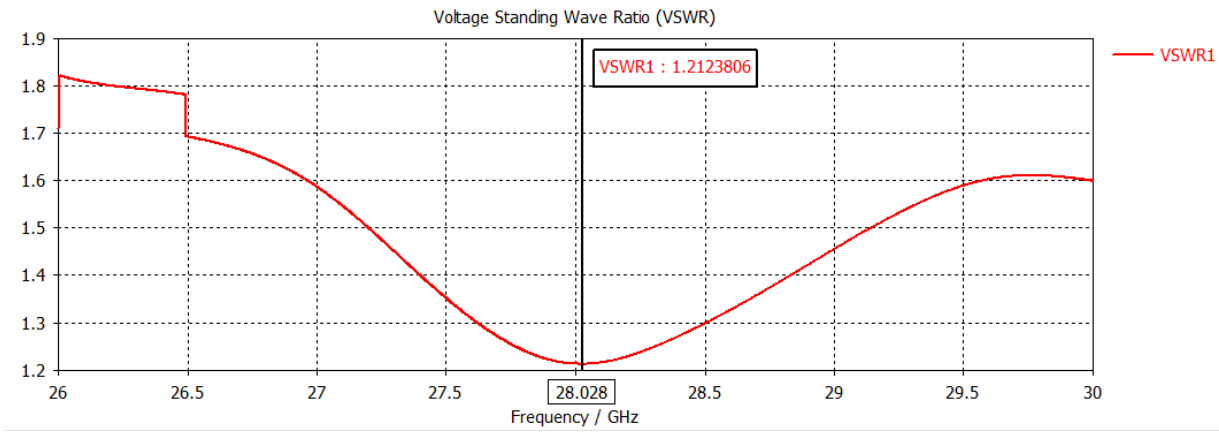

Gambar 9. VSWR Antena 1

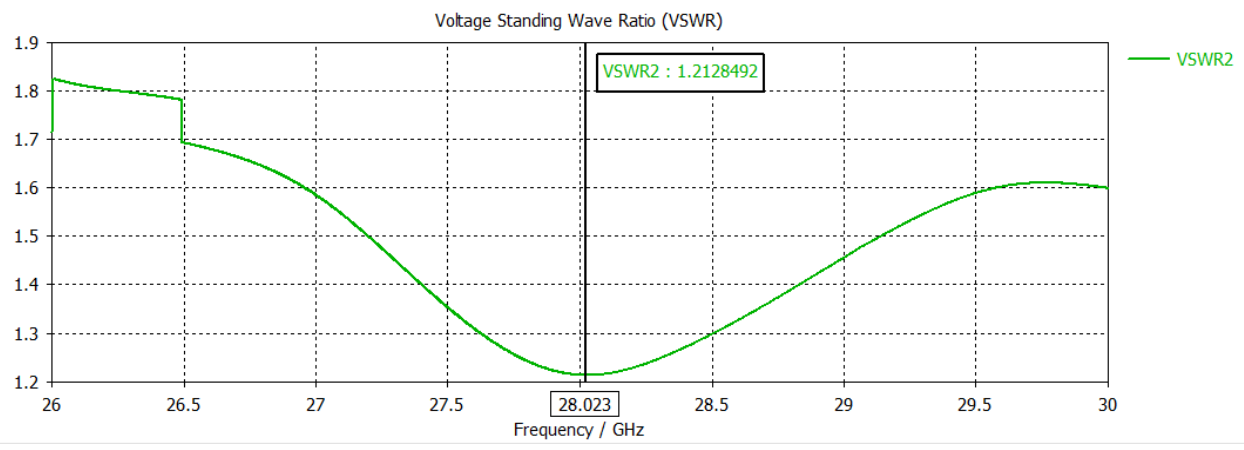

Gambar 10. VSWR Antena 2

Besarnya SLL yang diinginkan berdasarkan Tabel 1 adalah $\leq-13 \mathrm{~dB}$. Pada Gambar 11 didapatkan nilai SLL minimum di ANTENA 1 pada frekuensi $28 \mathrm{GHz}$ sebesar $-13,5 \mathrm{~dB}$. Pada Gambar 12 didapatkan nilai SLL minimum di ANTENA 2 juga sebesar -13,5 dB. 


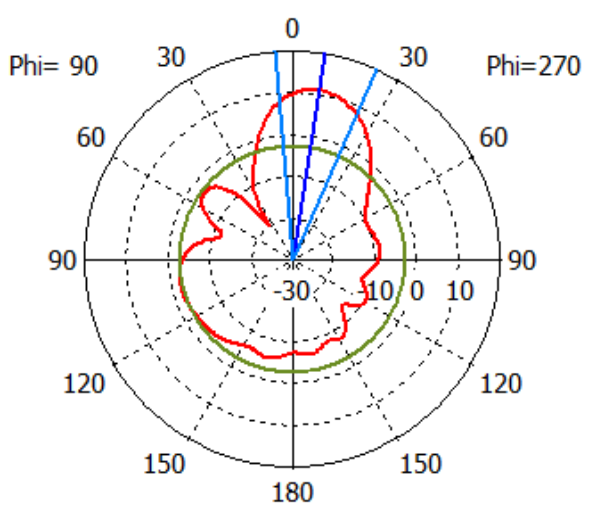

Theta / Degree vs. dB

Frequency $=28$

Main lobe magnitude $=\quad 11 \mathrm{~dB}$ Main lobe direction $=9.0 \mathrm{deg}$. Angular width $(3 \mathrm{~dB})=28.6 \mathrm{deg}$. Side lobe level $=-13.5 \mathrm{~dB}$

Gambar 11. Side Lobe Level Antena 1

Farfield Realized Gain Abs (Phi=90)

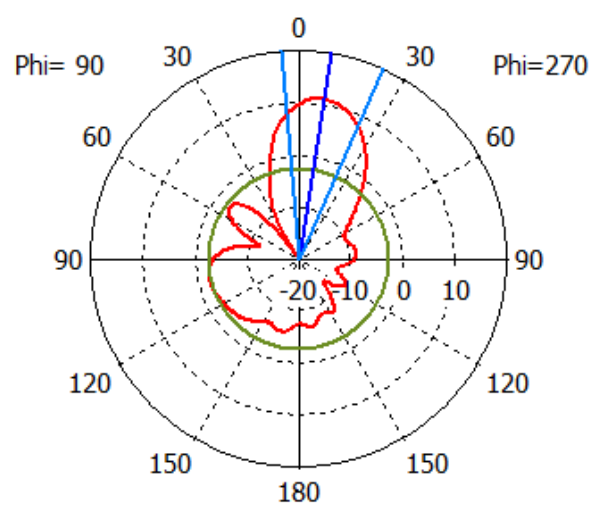

— farfield $(\mathrm{f}=28)$ [2]

Theta / Degree vs. dB

Gambar 12. Side Lobe Level Antena 2

\subsection{Hasil Simulasi Antena tanpa $\boldsymbol{U}$-slot Ganda}

Untuk memperoleh perbandingan hasil pengembangan $U$-slot ganda, maka dilakukan simulasi rancangan antena tanpa $U$-slot ganda sebagai pembanding. Pada Gambar 13 didapatkan nilai return loss di ANTENA 1 pada frekuensi tengah 28,069 GHz sebesar -12,284 dB dengan bandwidth sebesar $1,689 \mathrm{GHz}$. Pada Gambar 14 didapatkan nilai return loss di ANTENA 2 pada frekuensi tengah 28,069 GHz sebesar -12,295 dB dengan bandwidth sebesar 1,693 GHz. 


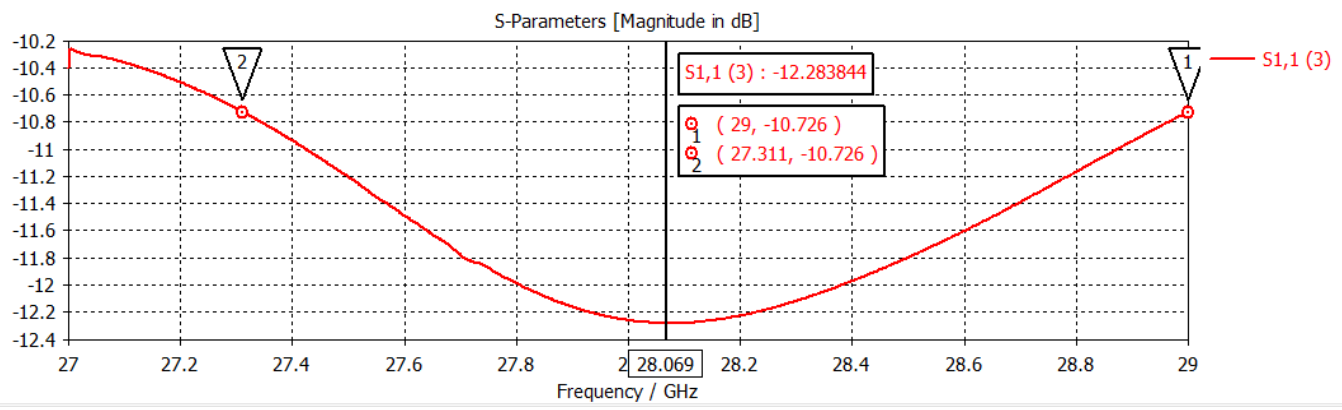

Gambar 13. Return Loss dan Bandwidth Antena 1

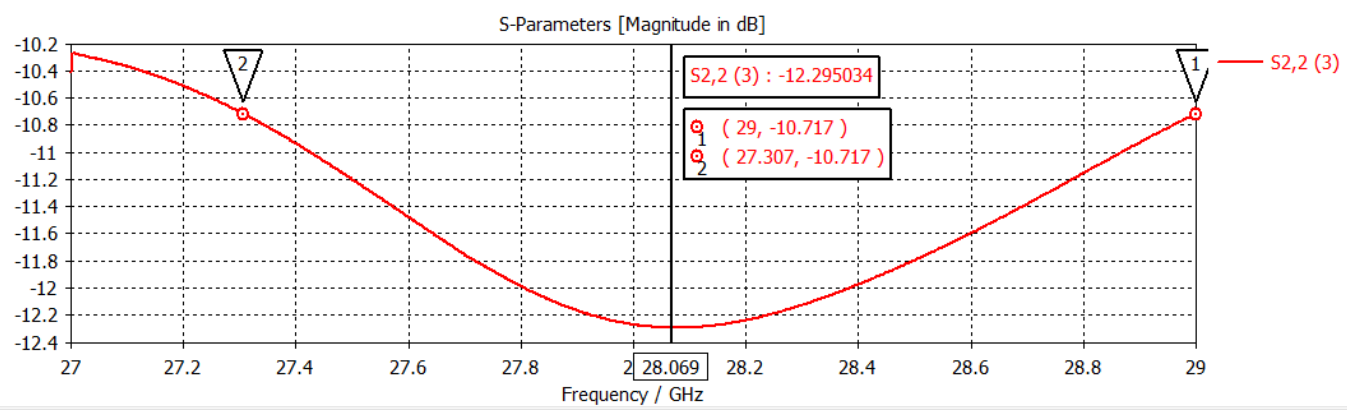

Gambar 14. Return Loss dan Bandwidth Antena 2

Besarnya gain yang diinginkan pada Tabel 1 spesifikasi antena adalah $\geq 9 \mathrm{~dB}$. Pada Gambar 15 didapatkan nilai gain maksimum di ANTENA 1 pada frekuensi $28 \mathrm{GHz}$ sebesar 10,86 dB dan pada Gambar 16 didapatkan nilai gain maksimum di ANTENA 2 pada frekuensi $28 \mathrm{GHz}$ juga sebesar $10,86 \mathrm{~dB}$.
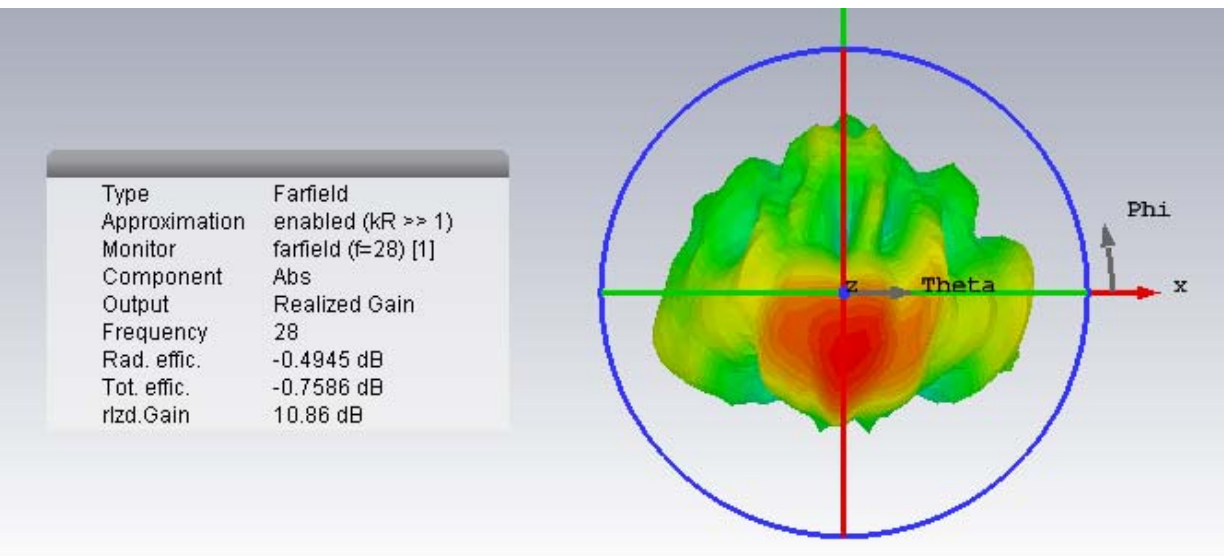

Gambar 15. Gain Antena 1 


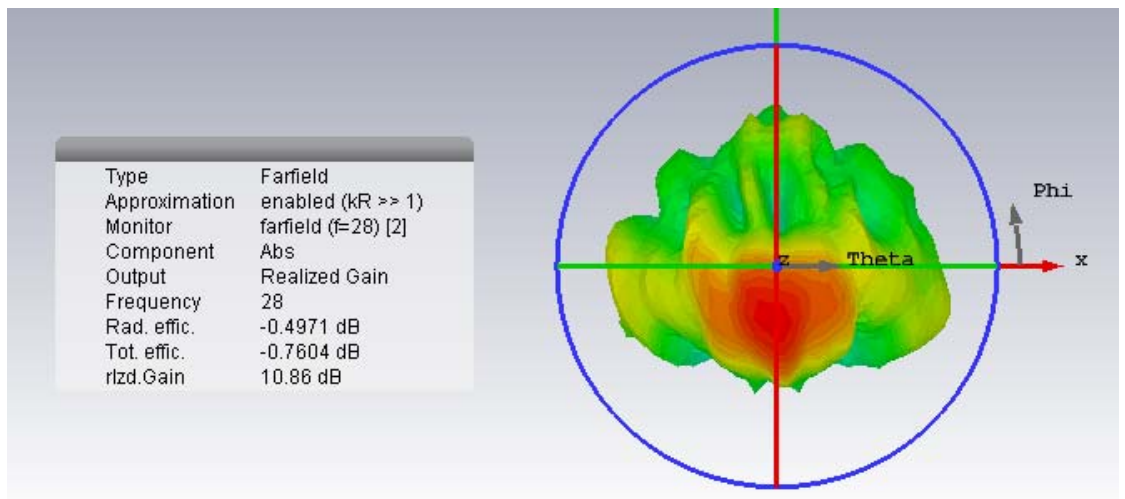

Gambar 16. Gain Antena 2

Pada Gambar 17 didapatkan nilai VSWR minimum di ANTENA 1 berada pada frekuensi tengah $28,069 \mathrm{GHz}$ dengan nilai sebesar 1,642 dan pada Gambar 18 didapatkan nilai VSWR minimum di ANTENA 2 pada frekuensi tengah 28,071 GHz dengan nilai sebesar 1,641.

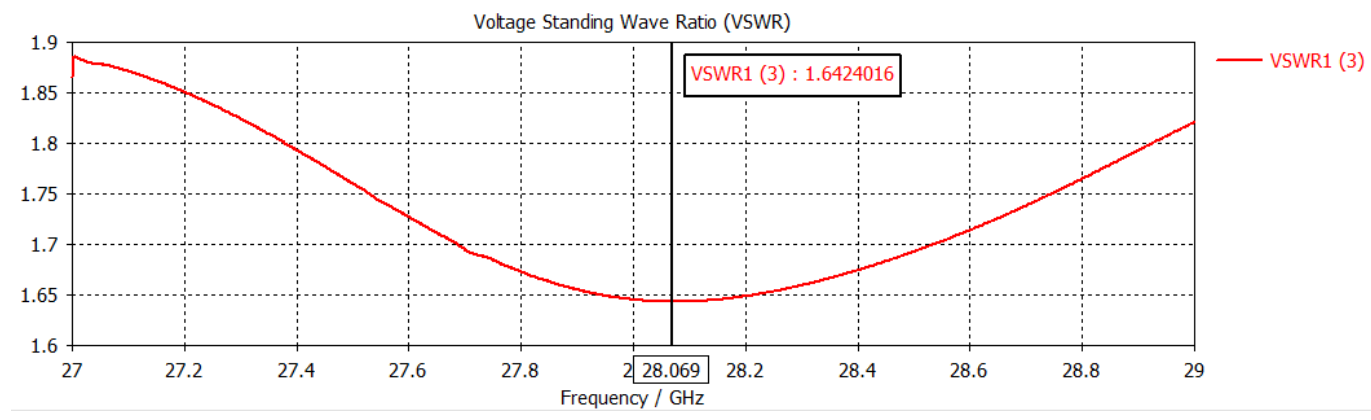

Gambar 17. VSWR Antena 1

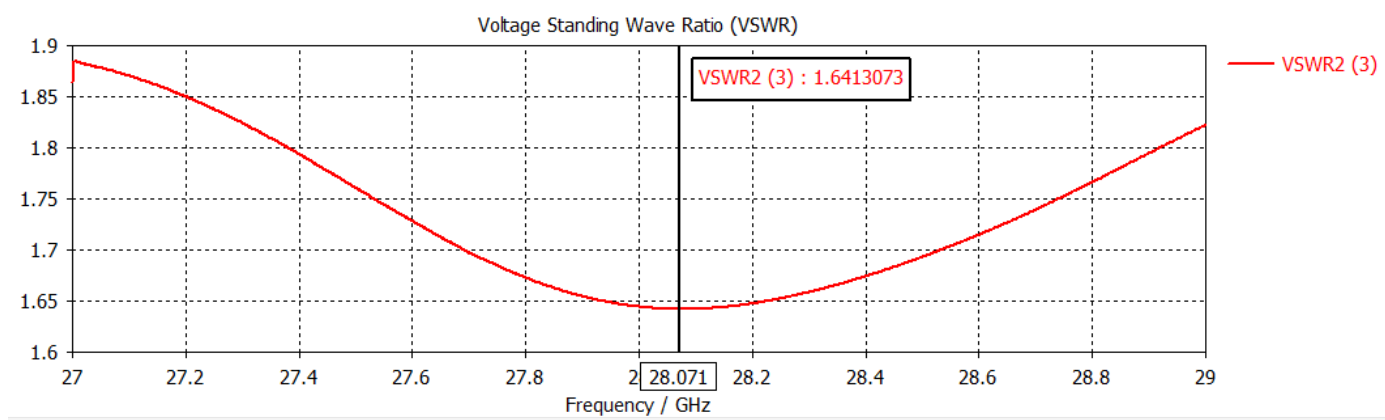

Gambar 18. VSWR Antena 2

Pada Gambar 19 didapatkan nilai SLL minimum di ANTENA 1 pada frekuensi $28 \mathrm{GHz}$ ialah sebesar -8,8 dB. Pada Gambar 20 didapatkan nilai SLL minimum di ANTENA 2 sebesar -8,9 dB. 
Farfield Realized Gain Abs (Phi=90)

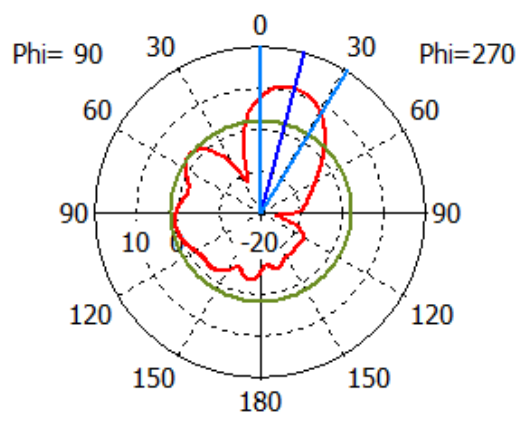
farfield $(f=28)[1]$

Frequency $=28$

Main lobe magnitude $=\quad 10.9 \mathrm{~dB}$

Main lobe direction $=15.0 \mathrm{deg}$.

Angular width $(3 \mathrm{~dB})=31.1 \mathrm{deg}$.

Side lobe level $=-8.8 \mathrm{~dB}$

Theta / Degree vs. dB

Gambar 19. Side Lobe Level Antena 1

Farfield Realized Gain Abs (Phi=90)

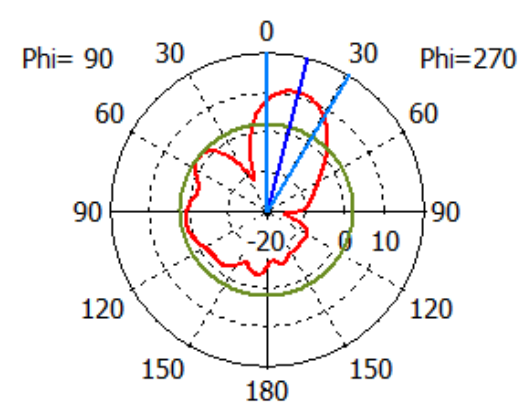

— farfield $(\mathrm{f}=28)$ [2]

Theta / Degree vs. dB

Gambar 20. Side Lobe Level Antena 2

\subsection{Analisis dan Perbandingan Peningkatan Bandwidth dan Gain}

Hasil penelitian (Kevin, dkk, 2017) tentang perancangan antena rectangular patch dengan U-slot pada frekuensi $15 \mathrm{GHz}$ dapat meningkatkan bandwidth sebesar $400 \mathrm{MHz}$ dibandingkan dengan antena tanpa U-slot. Penelitian (Ardianto, dkk, 2019) diperoleh peningkatan bandwidth $230 \mathrm{MHz}$ dan gain 0,44 dB jika dibandingkan tanpa rekayasa U-slot. Berdasarkan data pada penelitian menggunakan U-slot ganda, dihasilkan peningkatan bandwidth sebesar $1,156 \mathrm{GHz}$ jika dibandingkan dengan antena tanpa U-slot ganda. Penambahan U-slot ganda ini membuktikan peningkatan bandwidth $76 \%$ lebih besar dibandingkan dengan penggunaan $U$-slot tunggal pada penelitian-penelitian sebelumnya. Demikian juga peningkatan gain yang diperoleh mencapai $11,16 \mathrm{~dB}$, jauh lebih baik dari penelitian sebelumnya yang menghasilkan gain 9,2 dB. Perbandingan lengkap hasil penelitian U-slot ganda dengan tanpa U-slot dan penelitian sebelumnya seperti ditunjukkan Tabel 2. 
Tabel 2. Perbandingan Performansi Bandwidth dan Gain

\begin{tabular}{|c|c|c|c|c|}
\hline Parameter & $\begin{array}{c}\text { Proposal } \\
\text { U-slot Ganda }\end{array}$ & $\begin{array}{c}\text { Tanpa } \\
\text { U-slot }\end{array}$ & $\begin{array}{c}\text { Ardianto, } \\
\text { dkk, 2019 }\end{array}$ & $\begin{array}{c}\text { Kevin, dkk, } \\
\mathbf{2 0 1 7}\end{array}$ \\
\hline $\begin{array}{c}\text { Frekuensi } \\
\text { (GHz) }\end{array}$ & 28 & 28 & 28 & 15 \\
\hline $\begin{array}{c}\text { Bandwidth } \\
\text { (MHz) }\end{array}$ & 2,845 & 1,689 & 1,62 & 1,0 \\
\hline Gain (dB) & 11,16 & 10,86 & 7,52 & 9,2 \\
\hline
\end{tabular}

\section{KESIMPULAN}

Pada penelitian ini dirancang antena yang bekerja pada frekuensi $28 \mathrm{GHz}$ sebagai salah satu kandidat frekuensi 5G millimeter-wave dengan menggunakan rekayasa U-slot ganda untuk meningkatkan performansi bandwidth dan gain antena. Hasil simulasi menunjukkan bahwa rekayasa $U$-slot ganda yang diajukan mampu menghasilkan peningkatan bandwidth secara signifikan jika dibandingkan dengan tanpa U-slot dan hasil-hasil penelitian sebelumnya. Rekayasa U-slot ganda ini juga dapat meningkatkan gain antenna, namun tidak terlalu signifikan. Hasil desain antena MIMO 5G ini mampu menghasilkan bandwidth sebesar 2,845 $\mathrm{GHz}$ dan gain antena sebesar $11,16 \mathrm{~dB}$ atau meningkatkan bandwidth sebesar $68 \%$ dibandingkan tanpa $U$-slot dan $76 \%$ dibandingkan hasil penelitian sebelumnya. Hasil penelitian ini juga memberikan bukti tambahan bahwa rekayasa $U$-slot pada antena mikrostrip mampu meningkatkan bandwidth sehingga memberi kontribusi bagi pengembangan desain antena mikrostrip untuk berbagai aplikasi sistem komunikasi.

\section{DAFTAR RUJUKAN}

Ancans, G., Bobrovs, V., Ancans, A. and Kalibatiene D. (2017). Spectrum Consideration for 5G Mobile Communication Systems. Procedia Comput. Sci., 104, 509 - 516.

Ardianto, F. W., Renaldy, S., Lanang, F. F., Yunita, T. (2019). Desain Antena Mikrostrip Rectangular Patch Array 1x2 dengan U-slot Frekuensi 28 GHz. Elkomika, 71 ), 43 - 56. Balanis, C.A. (2005). Antena Theory Analysis and Design 3nd Edition. USA: Wiley Inter-science. Darimireddy, N.K., dkk. (2015). Design of triple-layer double U-slot patch antenna for wireless applications. Journal of Applied Research and Technology, 13(5), 526 - 534.

Ericsson Mobility Report. (2016). 5G radio access What is 5G?.

Garg, R. (2000). Microstrip Antenna Design Handbook. Boston: Artech House.

Hikmaturokhman, A., Ramli, K., Suryanegara, M. (2018). Spectrum Consideration for 5 G in Indonesia. International Conference on ICT for Rural Development (IC-ICTRuDev), (pp. 23-28).

Kevin, J., Levy Olivia N \& Syihabuddin. (2017). Perancangan Antena MIMO 2×2 Array Rectangular Patch dengan U-Slot untuk Aplikasi 5G. JNTETI, 6(1), 93 - 98. 
Kim, Y., Lee, H., Hwang, P., Patro, R. K., Lee, J., Roh, W. and Cheun, K. (2016). Feasibility of Mobile Cellular Communications at Millimeter Wave Frequency. IEEE Journal of Selected Topics in Signal Processing, 10(3), 589 - 599.

Recommendation ITU-R.2083-0. (2015). IMT Vision: Framework and Overall Objectives of the Future Development of IMT for 2020 and Beyond. ITU-R Radio Communication Sector of ITU.

Suaibur, R., Mowla, M. \& Mahabub Alam. (2013). Design \& Simulation of Double U-Slot Microstrip Patch Antenna for WiMAX Application. International Journal of Scientific Engineering Research, 4(7), 2013.

Swindlehurst, A. L., Ayanoglu, E., Heydari, P. and Capolino, F. (2014). Millimeter-Wave Massive MIMO: The Next Generation Revolution? IEEE Communications Magazine, 52(9), 56 62.

V.P., Patil. (2012). Enhancement of Bandwidth of Rectangular Patch Antenna Using two Square Slots Techniques. International Journal of Engineering Sciences \& Emerging Technologies, 3(2), 1 - 12.

Warren, D. and Dewar, C. (2014). Understanding 5G: Perspectives on Future Technological Advanced in Mobil. GSMA Intelligence. 